\title{
THE CRISIS OF SOCIALISM AND THE THIRD WORLD
}

\author{
by FRANZ J. HINKELAMMERT
}

This document was sent to us by our associate Joseph Owens, a Jesuit priest who has worked extensively throughout Latin America. Its author is widely recognized as a leading liberation theologian. After leaving the economics department of the Free University of Berlin in 1965, he went to Chile where he worked with the Christian Democratic Party and with the government during Allende's presidency. Currently he is working at the Departamento Ecuménico de Investigaciones in San José, Costa Rica. It is our conviction that this article represents one important trend in liberation theology which is attempting to address the changing contours of the anti-imperialist struggle and the crisis of socialism as it has manifested itself in Latin America.-The Editors

I should like to work out several theses on the change in the relationship between the countries of the Third World and those of the First. The crisis of the Third World has been strongly conditioned by the crisis of socialism in the former Soviet Union and the countries of Eastern Europe. It involves a profound change that took place in the 1980 s but had been foreshadowed in prior decades.

\section{Thesis One}

It is my belief, and this constitutes the first thesis, that a transformation has occurred in world capitalism in recent 
times. It came to the fore during the most dramatic moment in the crisis of socialism - the fall of the Berlin Wall in November, 1989. At that moment I was in the Federal Republic of Germany, and for me there existed a symbolic connection between that collapse and the massacre of the Jesuit community in San Salvador a week later. What struck me first of all was the fact that the European media stressed almost exclusively the fall of the wall, while the massacre was treated to a few marginal reports on the radio and in some of the newspapers. It involved a "liquidation" in the classical totalitarian style of the 1930s, instigated by the government of the United States. The FBI subsequently kidnapped the most important witness and forced her to change her testimony. One month later came the military intervention in Panama, to which all the Western governments acquiesced. The news coverage of that intervention, which was very meager thanks to the indifference of the media, also echoed the classical totalitarianism of the 1930s. On the afternoon of the first day the journalist of the Spanish newspaper El Pais was killed; this gave an unmistakable signal to the rest of the media that were on the scene.

There was no necessary, direct connection between the fall of the wall and the massacre in El Salvador, although the timing is suggestive of one. But few historical conjunctures in recent years have been as favorable as this one for an event such as the San Salvador massacre. With the fall of the wall, capitalism was free to let fall its mask and to abandon any pretense of wearing a human face. In the world that is depicted in the media today, there is but one lord that rules over one empire that covers and encloses the entire world. There is therefore no place of refuge. The Third World finds itself completely isolated, with no Second World that it could in any manner ally itself with. To the extent that there are still remnants of the Second World, they have abandoned any solidarity with the Third and joined with the North against the South. As the saying goes in many parts of Latin America, the 
Second World had no choice but to join the First World in devouring the Third.

The capitalism of the 1950s and 1960s was engaged in economic and social reforms, which included concern for the development of Third World countries so as to forestall the rise of alternative political movements. But now that there remain no alternatives, capitalism can be as unbridled and rapacious as it chooses to be. Any dispassionate observer can see that the world is on a course toward the abyss, which capitalism makes no effort to alter. It rhetorically asks if there are alternatives, while doing all that it can do to make it seem as though there are none.

Thus our first thesis: The crisis of socialism has deeply wounded the Third World and simultaneously threatened the very survival of humanity.

\section{Thesis Two}

At the same moment that the Third World has been grievously weakened, developments have drastically altered the economic relationship between the Third World and the First to the point where we must ask whether the First World still needs the Third.

Historically, the production methods of the Third World were developed around the use of its labor force to extract raw materials from its natural resources. Now many "natural" raw materials are being supplanted by synthetic materials. This change has made much of the work force that formerly produced the natural materials superfluous. Of course some of the natural materials are still being produced, but it is becoming less and less possible to employ all of the workers formerly engaged in primary production. From the standpoint of the First World, these workers are relatively superfluous.

Of course, the Third World itself is still necessary to the First. Its air, its waters, and its earth are still needed as dumping grounds for poisonous refuse. Its raw materials are still needed, though in diminishing quantities. But its people are 
utterly without value. The First World has not abandoned the Third World, therefore, but has reached a new understanding that rests on a new technology, in which such people are no longer valued as labor power to be exploited. They are nothing but an impediment and a potential danger-not a relatively surplus population, but an absolutely surplus population.

As a direct consequence of this state of affairs, the concept of exploitation must undergo a parallel transformation. In classical Marxism, exploitation is understood as the appropriation by capital of a share of the product of labor. As such, there is no exploitation without the employment of labor power. But in an era in which joblessness is endemic in much of the world, being exploited is a privilege. The Marxian concept of exploitation made its appearance in a world in which unemployment was a problem of the downside of the business cycle. But now unemployment is endemic throughout much of the capitalist system, of which the Third World is a vast and integral part. In the Third World of today many people would consider themselves lucky to to be robbed of a portion of the product of their labor. And to an increasing extent this is true of the workers of the First World.

The overwhelming unemployment has stripped the Third World population of any semblance of power. He who is superfluous cannot participate in strikes, has no power of negotiation, cannot threaten. The proud slogan of the nineteenth century worker, "All wheels will stop turning if your strong arm wills it," can no longer be raised by the working peoples of the Third World. Although it still seemed possible during the time of the oil crisis, even then it was applicable only to a portion of the labor force in a few countries at an exceptional moment. The same is true for the slogan, "Proletarians of all countries, unite!" The peoples of the Third World have such minimal negotiating power that they have nothing to gain by proffering their solidarity.

Thus our second thesis: The countries of the First World still need those of the Third World, but they no longer need their peoples. 


\section{Thesis Three}

Under the present conditions, the Third World countries are losing the capacity to carry out any genuine development policies. Their sole possibility for "development" is to increase their ties to the world market. Under the rules of the present world order, this means, in the end, increased specialization in the production of raw materials, increased competition for the stagnating demand of the industrial nations, and continual foreign exchange crisis. For this reason the countries of Latin America cannot continue to develop in the traditional way. In order for them to be further integrated in to the world market, they would have to participate in world trade through growing exports of industrial products.

There are clear indications that the industrialized countries have no interest in seeing the Third World industrialize, and will not accept anything of the sort. On the contrary, all steps in this direction are systematically blocked. In spite of the fact that a few small countries might somehow still succeed in developing through industrialization, the tendency in the Third World is for stagnation or decline in the Third World industries that developed from the fifties through the seventies.

The problems of the world environment are entering more and more into the calculation. It goes without saying that the Third World cannot develop by following in the footsteps of the First. The environment simply could not stand it. Any considerable industrialization in the Third World would therefore force the First World to subject its own industrial structure and technology to the conditions of survival of humanity. Inasmuch as there is no possibility that this will be done, the First World is prepared to sacrifice the Third World to preserve its own industrial hegemony as long as possible.

Herein lies the importance of the foreign debt of the Third World, which gives the First World a means by which it can check the development of the poor countries of the world. 
This foreign debt has become the decisive means by which the First World circumscribes the indebted Third World, by which it dictates "structural adjustments" that make it impossible for these countries to industrialize. The foreign debt is an ideal instrument for this, since it suppresses industrialization in ways that apparently have nothing to do with it. The objective is obscured: what is visible is the debt of the Third World countries and their inability to pay it, not the determination of the First World to keep the Third from industrializing.

To sum up in a few words the policy of the First World, it is this: Never again Japan! Japan happened once, but it must never happen again. Could the First World possibly accept another Japan on the scale of Brazil? Of India?

Thus our third thesis: The metropolitan capitalist countries have lost interest in the development of the Third World, and have resorted to blocking it in all its manifestations.

\section{Some Thoughts on Solidarity}

At present there exists a solidarity among people in the Third World that is quite different from the workers' solidarity in the nineteenth century. Workers' solidarity was based on their unity of purpose and their consciousness of the power that derived from that unity. This made it possible to confront capital from a position of strength, in the form of a destructive power. The solidarity of a people that has become superfluous cannot evince strength. It cannot form the basis for a negotiating position. It is, however, a basis for mutual aid, as was the solidarity of the proletariat. It becomes a source of real strength to the extent that the groups excluded from society can make common cause with some of the groups that are included. This must be a solidarity that transcends the interests of any one group, but it must include the outcasts. It is a solidarity that is expressed in the "preferential option for the poor."

As we have seen, the tendencies in the capitalist system of today not only are the negation of such solidarity but also seem to preclude it. At the present time solidarity with and 
among the poor presupposes a confrontation with capitalism. At issue is the creation of a society that is just, participatory, and ecologically sustainable. Solidarity would mean nothing if it did not put forward an alternative to present-day capitalism and its destructive tendencies.

\section{Human Dignity}

Denying the possibility of such an alternative is the negation of oneness, of the common family of humanity. The denial of an alternative is therefore the denial of human dignity, which is not a matter of abstract principle but of concrete practice. Dignity cannot be separated from the content of everyday life. There is no dignity without food, shelter, education, health, and safety. If these necessities of life are lacking, if they are not a matter of human rights, then the concept is empty.

This much is clear. People who are regarded as superfluous and are forced to recognize this are thereby deprived of all dignity. And those who deny them dignity treat them with disdain and contempt. Such attitudes account for the remarkable name that the West gives to all liberation movements: cancer! I cannot think of a single liberation movement which has not been designated as a cancer either in Washington or in one of the capitals of Europe. A cancer to be excised! This is the way the bourgeois world relates to liberation movements. The last time that the term "cancer" was used in connection with Latin America was in reference to Nicaragua and the Sandinista movement. It was similarly applied to Libya, to Chile, and previously-this was perhaps the first instance-to Indonesia in 1965. This use of the word "cancer" is the equivalent of the Nazis' use of "parasite." It is universally applied to liberation movements in the Third World and, beyond that, to all types of dissidence.

If the relationship between the existence of alternatives and human dignity is taken seriously, then it may be seen as well that the attempt of the bourgeoisie to destroy all alternatives is an assault on human dignity itself. In bourgeois 
society people are not accorded the right to live in dignity. They may live in happiness and dignity if they manage to find space in the marketplace to acquire the means to do so. If they do not succeed, the market confirms that they possess neither dignity nor the right to claim it. Now, therefore, in the process of destroying alternatives and creating superfluous humanity, an attempt is being made to destroy the sense of dignity to such a degree that those who are made superfluous regard themselves as superfluous. It is my belief that the present ideological struggle turns on this point. It is a form of psychological warfare. I also believe that the crisis of socialism has opened up the possibility of bringing this negation of dignity to the forefront of discussion.

This is true not only in the Third World. A similar process of "creating superfluous humanity" is taking place in the First World, although to a more limited extent. The attempt to make people see themselves as superfluous, if it succeeds, leads them to destroy one another rather than to build solidarity. I believe that Nietzsche was the first to describe this phenomenon with the care it deserves. It is astonishing to what an extent he understood the tendency of superfluous people to destroy themselves and one another. Self-destructive patterns are being acted out at the present in such Latin American societies as the Dominican Republic, Honduras, Colombia, Peru, and Argentina.

\section{Struggling to Survive}

This process of self destruction forces us to recognize that in the present situation solidarity means something different from what it once meant. No longer is it sufficient to call for unity and mutual assistance. We must now help to regenerate the human dignity whose roots have been destroyed. We must stand up and cry out that capitalism without the possibility of solidarity is the negation of human dignity and we will not stand for that.

The fact that there are no alternatives that already exist in fully worked-out form is beside the point. Is the genocide 
of the Third World justified because its peoples-the victims-cannot present any alternative? If we cannot envision at present the alternatives to the destruction of the Amazon or the Himalayas, does this mean that their destruction ought to be allowed to continue? We know that such destruction of humanity and nature must stop and it is everyone's responsibility to seek for an alternative. Capitalism has embarked on the collective suicide of humanity. Shall we all rush lemming-like to our death because no one has worked out a defensible alternative to capitalism?

The historical alternatives which have come into being have passed away, but that is no reason for the sense of triumph that the bourgeoisie is celebrating today. Every failed alternative is but a failed attempt to escape collective suicide. The working out of alternatives is an historical process, a sequence of collective responses to collective challenges, not something that is hammered out at a congress or planning bureau. The evaluation of alternatives entails technical considerations that cannot be treated lightly. And evaluation is made all the more difficult by the monopoly of the bourgeoisie over the means of technical evaluation. Nonetheless, we must never cease to proclaim that there will be no human survival unless an alternative is found to the system that is being celebrated. Alternatives will arise only when all of the world's population is clamoring for them. Alternatives are not extruded from a sausage machine. They are discovered or invented only when it becomes perfectly clear that we cannot survive without them.

It is clear in a very general way that the elements of a new world economic and financial order must consist of a policy for raw materials and labor markets, a program for universal health and education, and market constraints that respect the ecological limits to growth. At this point in our history, one cannot talk of a class alternative, only of an alternative for all of humanity. But the process of searching for an alternative and the insistence that an alternative must be found are matters that are saturated with class. It is the dominant class 
that proclaims that there are no alternatives. Today the bourgeoisie has no adversary in the form of a class-for-itself, yet it continues to wage a class war even though it is almost entirely one-sided. There is no way of defeating the bourgeoisie on its own battleground, and if it does not come to realize that it is carrying itself to the abyss along with the rest of humanity, we are all lost. All we can do is resist as best we can, and remember the words of Marek Edelman, one of the leaders of the Warsaw ghetto uprising in 1944: "It is better to do something than to do nothing."

According to the materialist concept of history, the ultimately determining element in history is the production and reproduction of real life. More than this neither Marx nor I have ever asserted. Hence if somebody twists this into saying that the economic element is the only determining one, he transforms that proposition into a meaningless, abstract, senseless phrase.-Friedrich Engels 